DOI 10.14746/ssp.2014.2.2

\author{
Marek REWIZORSKI
}

Politechnika Koszalińska

\title{
Rola rynku w kształtowaniu się zarządzania globalnego ${ }^{1}$
}

\section{Wprowadzenie}

$\mathrm{U}$ progu XXI wieku zarówno państwowi, jak i pozapaństwowi aktorzy stosunków międzynarodowych stanęli przed koniecznością odnalezienia swojego miejsca w rzeczywistości, która jawi się jako coraz mniej klarowna. Podkreśla się zwłaszcza zachodzenie procesu „rekonfiguracji anarchiczności środowiska międzynarodowego". Proces ten wyraża się niespotykaną wcześniej heterogenicznością podmiotów działających „w poprzek” granic państwowych, a nie „w ich ramach”, czemu towarzyszy wyłanianie się wielu równoważnych centrów podejmowania decyzji, opierających swoje działanie na pluralizmie, współdziałaniu i odejściu od hierarchicznych relacji między aktorami terytorialnymi a nieterytorialnymi. Rekonfiguracji anarchiczności środowiska międzynarodowego towarzyszy idea zarządzania (governance). Wiąże się ona raczej ze sterowaniem niż rządzeniem, a więc z szerokim zakresem procesów, za pomocą których koordynuje się podejmowanie decyzji i wciela w życie określone polityki. Warto zauważyć, że zarządzanie polega na dostosowywaniu indywidualnych i zbiorowych sposobów rozwiązywania wspólnych spraw tak, aby rozwiązywać pojawiające się nieustannie konflikty, łagodzić różnice interesów i w rezultacie zwiększać pole możliwej współpracy między heterogenicznymi podmiotami. Zasadniczą rolę odgrywają tu rozmaite nieformalne i formalne instytucje. Ich intencje mogą stać się katalizatorem działań grupowych (Commission, 1995, s. 2).

Zasadniczą cechą odróżniającą governance od tradycyjnego porządku politycznego jest „rozmycie” hierarchicznego władztwa państwowego,

1 Niniejszy artykuł powstał w ramach projektu badawczego pt. „G-20 i triada instytucjonalna w systemie global governance" finansowanego ze środków Narodowego Centrum Nauki, przyznanych na podstawie decyzji DEC-2011/01/D/HS5/02220. 
a co za tym idzie odejście od „nakazu i kontroli” jako metody regulacji działań indywidualnych i zbiorowych. W rzeczy samej zarządzanie należy ujmować jako zestaw interakcji horyzontalnych, zachodzących między państwem a wchodzącymi z nim w rozmaite relacje aktorami społecznymi, korzystającymi z rozwiniętych układów sieciowych, partnerstwa prywatno-publicznego i innych narzędzi działania politycznego. Na przeciwległych biegunach zarządzania znajdują się zatem hierarchicznie zorganizowane państwa oraz samoorganizujące się, i w dużym stopniu zdecentralizowane, grupy społeczeństwa obywatelskiego, przybierające najczęściej formy organizacji pozarządowych, ruchów społecznych, organizacji non-profit ${ }^{2}$. Wykorzystują one do swego działania rynki, na których zachodzi alokacja zasobów i na których sformalizowane reguły narzucane przez państwo ulegają osłabieniu, przez co zarządzanie nabiera charakteru gospodarczego i finansowego (rys. 1).

$$
\begin{gathered}
\text { Rynek } \\
\text { C }
\end{gathered}
$$

interakcje polityczne

A Państwo interakcje polityczne interakcje gospodarcze i finansowe

interakcje gospodarcze i finansowe

Rys 1. Zarządzanie jako zespół interakcji horyzontalnych między państwem a społeczeństwem obywatelskim

Źródlo: Opracowanie własne.

2 W literaturze politologicznej wskazuje się, że w wyniku zmian, jakie niesie ze sobą globalizacja jest m.in. zwiększanie się liczby i szybkie rozprzestrzenianie się organizacji pozarządowych stanowiących bazę globalnego społeczeństwa obywatelskiego (ang. global civil society). To ostatnie obejmuje ,jednostki, przedsięwzięcia, przedsiębiorstwa, organizacje non-profit, ruchy społeczne, różnorodne wspólnoty, sławne osobistości, intelektualistów, think-tanki, organizacje charytatywne, grupy nacisku, ruchy protestu, media, grupy i strony internetowe, związki zawodowe, federacje pracodawców, komisje międzynarodowe, organizacje sportowe, wszystkie tworzące wielopoziomową, gęsto powiązaną przestrzeń”. Por. E. Pietrzak, Niepostuszeństwo i profanacje - globalne społeczeństwo obywatelskie, „Przegląd Politologiczny” 2013, nr 1 , s. 85 . 
Aplikując ideę zarządzania na poziom globalny, należy zauważyć, że u jego podstaw leżą współczesne przemiany zachodzące $\mathrm{w}$ technice, transporcie, a nade wszystko komunikacji. Zwłaszcza skrócenie czasu potrzebnego na przetwarzanie i przesyłanie informacji służy wzmocnieniu rozmaitych form transnarodowych organizacji politycznych. Wspomniane przemiany są eksponowane zwłaszcza przez zwolenników neoliberalizmu. Dowodzą oni, że model państwowocentryczny jest nieadekwatny wobec coraz bardziej złożonych problemów regulacyjnych, których rozwiązanie wymaga „dobrego zarządzania”. Nie może być ono zapewnione przez państwa bez udziału rynków (zwłaszcza sektora biznesowego) i globalnego społeczeństwa obywatelskiego ${ }^{3}$. Przykładem tego są coraz bliższe relacje, do których dochodzi między państwami wchodzącymi w skład grup takich jak G-8 czy G-20 a instytucjami biznesowymi. Mimo, że reprezentanci państw w G-8 czy G-20 odróżniają podmioty sektora biznesowego od organizacji pozarządowych typu non profit, pojawia się coraz więcej argumentów za włączeniem sektora biznesowego w obręb społeczeństwa obywatelskiego, przez co to ostatnie może zyskać większą zdolność nacisku na struktury systemu $\mathrm{Gx}^{4}$. O tym, że takie rozwiązanie jest prawdopodobne, świadczy rozbudowany program szczytu G-20 w St. Petersburgu (2013), w którym obok przedstawicieli społeczeństwa obywatelskiego uczestniczyli również reprezentanci sektora biznesowego, tzw. Business 20 (B20). Grupa ta pod przewodnictwem rosyjskim po raz pierwszy spotkała się 12 grudnia 2012 w Moskwie. Pół roku później, w dniach 20-21 czerwca 2013, na jej kolejnym szczycie (przeprowadzo-

3 Wyżej wskazane poglądy nie są nowe. Wywodzą się one z tradycji myśli politycznej Zachodu, akcentującej znaczenie mechanizmów wolnorynkowych, wzajemności, zaufania i solidarności. Kontrastują z kontrolą i podporządkowaniem, jako ideami na wskroś antyliberalnymi. Cf. W. Streeck, P. C. Schmitter, Community, Market, State-and Associations?, „European Sociological Review” 1985, Vol. 1, s. 119-38.

4 Wyrażenie „System Gx” zostało po raz pierwszy użyte przez Fundację Stanleya w 2009 r. Mowa tu o G-7, G-8 i G-20 - niesformalizowanych klubach, forach współpracy międzynarodowej tworzących specyficzny system o strukturze sieciowej. W ramach systemu organizowane są nieformalne spotkania, z których najważniejszą rolę pełnią „szczyty” organizowane na poziomie przywódców państw (G-20 Leaders'). Spotkaniom na najwyższym szczeblu towarzyszą konsultacje prowadzone na niższych poziomach: ministrów, szerpów, grup roboczych oraz zespołów zadaniowych. Cf. The Stanley Foundation, Courier. Waiting to Join the Club, nr 63, lato 2009; P. Hajnal, The G8 system and the G20: evolution, role and documentation, Ashgate, Aldershot 2007, s. 1. 
nym także w Moskwie) przyjęto białą księgę (B20, 2013a), która wraz $\mathrm{z}$ raportem przygotowanym przez powołaną $\mathrm{w}$ ramach B20 Grupę Zadaniową ds. Efektywności Dialogu (B20 Dialogue Efficiency Task Force) (B20, 2013b) stała się podstawą zacieśniania relacji między globalnym biznesem a G-20. Wspomniane już szczyty G-8 i G-20 stały się okazją do współpracy prowadzącej do nadania rynkom „bardziej społecznego wymiaru", wpisującego się w koncepcję zrównoważonego rozwoju. Uczestniczą w nich nie tylko ministrowie gospodarki z państw G-20, ale także znane osobistości ze świata ekonomii, jak Bill Gates, założyciel firmy Microsoft, który uczestniczył w szczytach grupy dwudziestu w Cannes (2011) i Los Cabos (2012). Należy zauważyć, że było to uczestnictwo czynne. Na spotkaniu liderów G-20 w Cannes Bill Gates przedstawił nawet własny raport odnoszący się do współpracy między różnymi grupami biznesowymi a przedstawicielami globalnego społeczeństwa obywatelskiego w zakresie rozwoju i ochrony zdrowia (Gates, 2011). W ten kontekst wpisują się także działania osobistości globalnego rynku muzycznego, m.in. Bono i Boba Geldofa, występujących na koncertach „Live 8” przed szczytem G-8 w Gleaneagles (2005), współpracujących z G-8 i G-20 w ramach kampanii ONE/DATA (Debt, Aids, Trade, Africa), a także współwydających w maju 2010 r., przed szczytem G-8, specjalny numer kanadyjskiego pisma „The Globe and Mail”, poświęconego w całości problemom Afryki.

Należy zauważyć, że wymieniony tu kilkukrotnie „rynek” jest jednym z najważniejszych obszarów zachodzenia skomplikowanych zależności, w które uwikłane są zarówno państwa, jak również podmioty niepaństwowe. Interakcje zachodzące między nimi mogą prowadzić do usprawnienia mechanizmów zarządzania globalnego, np. w zakresie handlu, finansów czy ochrony środowiska, choć $\mathrm{w}$ rzeczywistości bywa $\mathrm{z}$ tym różnie. Współczesne przemiany zachodzące głównie na polu ekonomicznym i politycznym mogą stanowić swego rodzaju zagrożenie dla państw i ich pozycji w systemie międzynarodowym. Nie da się bowiem ukryć, że ,system międzynarodowy" w coraz mniejszym stopniu zależny jest od woli państw, stając się w istocie sieciową strukturą tworzoną przez ,państwa, uczestników niepaństwowych, relacje i powiązania między nimi, obowiązujące zasady prawa międzynarodowego oraz międzynarodowe reżimy, sojusze i instytucje" (Łoś-Nowak, 2011, s. 28-29). Warto zatem poświęcić refleksję rynkowi jako obszarowi krystalizowania się nowego układu zależności między państwem a aktorami niepaństwowymi, a także wskazać na relacje między nimi. 


\section{Globalizacja a ekspansja rynku}

Znaczenie rynku jako jednej z płaszczyzn, na której zachodzą relacje polityczne, ekonomiczne, finansowe między państwami i podmiotami niepaństwowymi, rośnie. Główną tego przyczyną jest postęp procesu globalizacji polegającej na poszerzaniu, pogłębianiu i przyspieszaniu gospodarczych, politycznych, społecznych i kulturowych współzależności między jednostkami, grupami, organizacjami, państwami i innymi podmiotami systemu międzynarodowego (Brown, 2008, s. 45; Naim, 2009, s. 29). Rynek stanowi punkt odniesienia w dyskusji na temat gospodarczych aspektów globalizacji. Istotne znaczenie przypisuje mu m.in. Immanuel Wallerstein i skupieni wokół niego badacze, tacy jak: Craig N. Murphy (Murphy, 1994), Ernest Mandel (Mandel, 1975), Michael Zürn (Zürn, 1995) oraz Henk W. Overbeek (Overbeek, 2005). Ten ostatni wskazuje na stopniowe, trwające ponad kilkaset lat pogłębianie się znaczenia rynków towarowych, stanowiących fundament współczesnego kapitalizmu. Zdaniem Overbeeka, globalizacja jest w istocie narracją historyczną zachodzącą na gruncie ekonomicznym, opisującą proces komodyfikacji (od angielskiego słowa commodity - towar), polegający na przetwarzaniu, transformowaniu rzeczy czy działań w produkty (towary) i usługi sprzedawane na rynku. Wiąże się z wykształceniem rynku globalnego, mającego początkowo charakter towarowy, później zaś także usługowy (Overbeek, 2005). Współczesny wymiar przybrał on w latach 70. i 80. ubiegłego wieku i trwa również obecnie. Zdaniem Overbeeka, w ciagu ostatnich 30 lat na rynku nastąpiło pogłębienie działań, transakcji i powiązań charakteryzujących się: 1) ilościowym wzrostem jego różnorodnych form (np. zwiększeniem integracji rynków finansowych, wzrostem udziału usług w handlu międzynarodowym, rozwojem handlu wewnątrzgałęziowego, ekspansją przedsiębiorstw trans- i wielonarodowych, wzrostem znaczenia regulacji międzynarodowych o znaczeniu ,globalnym” kosztem przepisów krajowych, deregulacją rynków finansowych, międzynarodową mobilnością kapitału, wzrostem fuzji i akwizycji, istnieniem niewielkich państw, posiadających wysoki stosunek obrotów handlu zagranicznego do PKB »Tajwan, Singapur, Finlandia, Irlandia«); 2) urynkowieniem sektorów dotychczas poddanych kontroli państwa (prywatyzacją przedsiębiorstw państwowych, także tych o strategicznym znaczeniu dla gospodarki narodowej, np. w sektorze telekomunikacyjnym, transportowym, energetycznym); 3) inkorporacją (z pewnymi odrębnościami, na co wskazuje przykład Chin, państw skandynawskich) poszczególnych państw, a nawet regionów 
w ramy kapitalistycznego rynku globalnego, programowo odrzucającego gospodarki oparte na modelu socjalistycznym; 4) podporządkowaniem poszczególnych sfer aktywności ludzkiej, także bardzo „,zindywidualizowanych", jak: reprodukcja czy twórczość artystyczna, bezosobowym i zautomatyzowanym siłom rynkowym. Zdaniem Overbeeka, wskazane przemiany rynku ukształtowały współczesny obraz globalizacji neoliberalnej, której „znakiem firmowym” w ostatnich trzydziestu latach jest ekspansja transnarodowego kapitału na niespotykaną dotąd skalę (Overbeek, 2005, s. 43).

\section{Rynek, władztwo prywatne i transrządowe sieci regulacyjne a zarządzanie globalne}

Wspomniane procesy, cechujące się wysoką dynamiką, pozwalają na postawienie tezy, że w idei rynku ucieleśniona jest zasada szczególnego porządku, gdzie współpraca oparta jest bardziej na wzajemnej korzyści, niż na politycznej hierarchii i sztywno ustalonych wartościach. Rynek odgrywa zasadniczą rolę w aspekcie wykształcania się globalnego zarządzania ekonomicznego. Pozwala na odróżnienie rządzenia (governing) do zarządzania (governance). I tu warto poczynić pewne uwagi. Można bowiem zauważyć, że w debacie na temat roli rynków jako podstawy rozwijania zarządzania gospodarczego, rysuje się kilka stanowisk. Dla niektórych badaczy rynek ma charakter normatywny. W tym sensie jest on gwarantem wolności i instrumentem demokratycznej zmiany. Dla innych funkcjonowanie rynków, także tych globalnych, jest niewystarczające do tego, by rozwiązywać problemy globalne, i to bez względu na to czy dotyczą one zmian klimatycznych, nierównego rozwoju gospodarczego, czy rosnącego rozwarstwienia społecznego. Dla zwolenników opcji wolnorynkowej interwencja państwa jest zawsze najgorszym rozwiązaniem. Dla neoliberałów ,interwencje państwowe na rynkach muszą być ograniczone do minimum, ponieważ państwo nie jest w stanie pozyskać wystarczająco dużo informacji, aby odgadnąć sygnały rynkowe (ceny), a potężne grupy interesu będą niechybnie zniekształcać i naginać interwencje w celu uzyskania przez siebie korzyści” (Harvey, 2005, s. 2). Istnieje też pogląd, że rynek opanowany przez siły neoliberalne jest narzędziem, dzięki któremu globalizacja relatywnie osłabia rolę państwa, spychając je na pozycję peryferyjną. Na perspektywę ,zawłaszczenia” przestrzeni ekonomicznej i społecznej przez neoliberalizm jako strukturalną przyczynę kryzysów 
gospodarczych zwracają uwagę m.in. David Harvey (Harvey, 2005), Jerzy Żyżyński (Żyżyński, 2009, s. 163-188) oraz Grzegorz Kołodko (Kołodko, 2008; Kołodko, 2010a, s. 117-125). Według G. Kołodki rozprzestrzenianie się neoliberalizmu jest główną przyczyną kryzysów finansowych, w tym obecnego, przyrównywanego do wielkiej depresji z lat 1929-1933. Pytając, „dokąd zmierza świat” (Kołodko, 2013), zauważa on, że „korzenie kryzysu tkwią głęboko w neoliberalnym kapitalizmie. Nie mógł on się zrodzić w krajach ze społeczną gospodarką rynkową [...], ale tylko w warunkach neoliberalnego modelu angloamerykańskiego"(Kołodko, 2010b, s. 95). Badacz ten nie bez racji doszukuje się przyczyn kryzysogennych zjawisk i procesów w typowej dla neoliberalizmu kombinacji wartości, instytucji i polityki. W jego ujęciu wartości nadmierną rolę przypisuje się indywidualizmowi i gloryfikuje chciwość, która negując społeczne aspekty gospodarowania, prowadzi do „ufinansowania bez mała wszystkiego” (Kołodko, 2010b). Od strony instytucjonalnej neoliberalizm sprzeciwia się interwencjonizmowi, a co za tym idzie neguje państwo i jego rolę jako drugiej, obok rynku, instytucji współczesnej gospodarki. Celem zaś nie neoliberalnej polityki nie jest zrównoważony rozwój (także społecznie i ekologicznie), lecz świat bezinflacyjny (ang. zero-inflation world) oraz dbanie o niezależność banków centralnych i stabilność pieniądza przy jednoczesnym odsuwaniu na boczny tor pozostałych celów, takich jak np. walka $\mathrm{z}$ bezrobociem.

Przytoczone poglądy wskazują na relatywne osłabienie pozycji państwa względem sił i podmiotów rynkowych podejmujących działania na szeroką skalę w dziedzinie gospodarki, handlu, finansów i prawa. Thomas J. Biersteker i Rodney Bruce Hall określają sferę aktywności tychże aktorów mianem ,,prywatnego władztwa w zarządzaniu globalnym" (Biersteker, Hall, 2002). W ostatnich latach można znaleźć coraz więcej jego przykładów. Jednym z nich jest prywatny arbitraż handlowy, oferowany przez międzynarodowe firmy, których liczba wzrosła z 10 w 1919 roku do ponad 100 w 1985 r. Posługują się one międzynarodowym prawem handlowym skodyfikowanym w ramach zasad umów handlowych określanych przez Międzynarodowy Instytut Unifikacji Prawa Prywatnego (International Institute for the Unification of Private Law - UNIDROIT) (Mattli, 2001, s. 919-47). Inny przykład stanowi działalność prywatnych agencji ratingowych (credit rating agencies) zajmujących się oceną wiarygodności kredytowej podmiotów pożyczających pieniądze, czyli spółek, funduszy, banków, organizacji i rządów państw oraz oceną samych instrumentów dłużnych wykorzystywanych na ryn- 
kach ekonomicznych ${ }^{5}$. Procedurze przyznawania oceny wiarygodności finansowej poddają się najpoważniejsze i największe instytucje finansowe świata, a także państwa i miasta. Według ratingu agencji Standard \& Poor's z listopada 2013 roku jedynie 14 państw otrzymało oceny na poziomie najwyższym (AAA) ${ }^{6}$. Należą do nich: Wielka Brytania, Szwecja, Singa-

${ }^{5}$ Rynek agencji ratingowych kontroluje kilka firm z USA. Zalicza się do nich: Fitch Ratings, Moody's, Standard \& Poor's, A.M. Best i Dominion Bond Rating Service. Oprócz tego na rynku działa kilka firm i instytucji, które pełnią rolę narodowych agencji ratingowych w swoich krajach, np. Japan Credit Rating Agency czy Malaysian Rating Corporation. Ich oceny wiarygodności kredytowej mają jednak mniejsze znaczenie w skali międzynarodowej, choć stanowią lokalnie przeciwwagę dla ratingów publikowanych przez agencje amerykańskie. W Polsce także działają agencje ratingowe o charakterze lokalnym, mianowicie Agencja Ratingowa EuroRating i Agencja Ratingowa AFS. Globalny rynek ratingu charakteryzuje się stopniowymi fuzjami i przejęciami narodowych oraz mniejszych międzynarodowych agencji ratingowych. Na przykład Standard \& Poor's w 1990 r. przejęła agencje Insurance Solvency International Ltd. oraz Ducan Andrew, a w 1995 r. francuską agencję Agence d'Evaluation Financiere (ADEF). Agencja Fitch dokonała w 1997 r. fuzji z IBCA Ltd., a następnie przejęła kolejno agencje Duff and Phelps Credit Rating Co. (kwiecień 2000 r.) oraz Thomson Bank Watch (grudzien 2000 r.). Według raportu Swiss Re, 80\% wszystkich przychodów agencji ratingowych na całym świecie przypada po połowie na Standard \& Poor's oraz Moody's, $14 \%$ na Fitch, $4 \%$ na A.M. Best, a zaledwie $2 \%$ na pozostałe agencje. W Polsce do przejęć doszło w grudniu $1998 \mathrm{r}$. Agencja Thomson Financial Bank Watch, obejmując 43\% akcji Środkowoeuropejskiego Centrum Ratingu i Analiz SA (CERA SA), została jego strategicznym akcjonariuszem. Dwa lata później 52,5\% udziałów w agencji objęła międzynarodowa agencja Fitch, zmieniając następnie nazwę spółki na Fitch Polska. W Polsce nadaje ona oceny ratingowe emitującym papiery wartościowe gminom, wybranym branżom oraz spółkom (m.in. Rheinhyp-BRE Bank Hipoteczny SA, Orbis SA, Polska Grupa Farmaceutyczna SA, Ostrów Wielkopolski, Płock, Kielce, Olsztyn, Rybnik) oraz bankom (m.in. Bank Gospodarki Żywnościowej SA, Bank Handlowy w Warszawie SA, Bank Ochrony Środowiska SA, Bank Pekao SA, BPH PBK SA, Bank Zachodni WBK). Por. J. M. Ammer, F. Packer, How Consistent Are Credit Ratings? A Geographic and Sectorial Analysis of Default Risk, FRB International Finance Discussion Paper, $\mathrm{nr}$ 668, czerwiec 2000, http://ssrn.com/abstract=232909; A. W. A. Boot, T. M. Tood, A. Schmeits, Credit Ratings as Coordination Mechanisms, „Review of Financial Studies" 2006, Vol. 19(1), s. 81 i n.; J. Brylak, Agencje ratingowe na rynku inwestycji. Prawne aspekty instytucji, Polskie Towarzystwo Naukowe, „Zeszyty Naukowe” 2011, nr 11 , s. $311-314$.

${ }^{6}$ Należy jednak zauważyć, że w praktyce ratingi znacznie odbiegają od rzeczywistości. Powodem tego może być fakt, że agencje opierają się często na danych historycznych, a także na modelach matematycznych, które nie uwzględniają najważniejszych, w okresie kryzysu, parametrów psychologicznych oraz nieprzewidywalnych zmian na rynku, jak załamanie notowań inwestycji nieruchomości. 
pur, Szwajcaria, Norwegia, Holandia, Luksemburg, Lichtenstein, Hong Kong, Australia, Kanada, Dania, Niemcy i Finlandia. Dla Polski rating określony został na poziomie A, zaś dla Hiszpanii i Grecji wyniósł on odpowiednio BBB-i B (Standard, 2013). Poniżej w tabeli 1. zamieszczono oznaczenia, którymi posługują się agencje ratingowe przy ocenie wiarygodności swoich klientów.

Tabela 1

Oznaczenia ratingowe używane przez agencję Standard \& Poor's

\begin{tabular}{||l|l||}
\hline \multicolumn{1}{|c|}{ Oznaczenie } & \multicolumn{1}{|c|}{ Wiarygodność kredytowa } \\
\hline AAA & Brak ryzyka kredytowego \\
\hline $\begin{array}{l}\text { AA+ } \\
\text { AA } \\
\text { AA- }\end{array}$ & Bezpieczna inwestycja, niewielkie ryzyko upadłości \\
\hline $\begin{array}{l}\text { A+ } \\
\text { A } \\
\text { A- }\end{array}$ & $\begin{array}{l}\text { Bezpieczna inwestycja, chyba, że w gospodarce lub w branży wystąpią nie- } \\
\text { przewidywalne zjawiska }\end{array}$ \\
\hline $\begin{array}{l}\text { BBB+ } \\
\text { BBB } \\
\text { BBB- }\end{array}$ & $\begin{array}{l}\text { Średnio bezpieczna inwestycja. Zauważalne pogorszenie kondycji gospo- } \\
\text { darki }\end{array}$ \\
\hline $\begin{array}{l}\text { BB+ } \\
\text { BB } \\
\text { BB- }\end{array}$ & $\begin{array}{l}\text { Spekulacyjna inwestycja. Znaczne problemy gospodarcze wpływają na } \\
\text { duże ryzyko inwestycyjne }\end{array}$ \\
\hline $\begin{array}{l}\text { B+ } \\
\text { B } \\
\text { B- }\end{array}$ & Spekulacyjna inwestycja. Bardzo duże ryzyko inwestycyjne \\
\hline $\begin{array}{l}\text { CCC } \\
\text { CC } \\
\text { C }\end{array}$ & Wysokie ryzyko bankructwa \\
\hline D & Podmiot w upadłości lub trwale niezdolny do regulowania zobowiązań \\
\hline
\end{tabular}

Źródło: J. Brylak, Agencje ratingowe na rynku inwestycji. Prawne aspekty instytucji, Polskie Towarzystwo Naukowe, ,Zeszyty Naukowe” 2011, nr 11, s. 317; A. Słojewska, Agencje: wróg publiczny $n r$ 1, „Rzeczpospolita”, 15.07.2011.

Agencje ratingowe stanowią element opiniotwórczy gospodarki wolnorynkowej dzięki posiadaniu wysokiej wiarygodności i zachowywaniu całkowitej niezależności od inwestorów (lobby kapitałowego) i środowisk politycznych. Nade wszystko jednak sfera ich ,władztwa” widoczna jest na rynkach finansowych. Sukces większości emitowanych papierów dłużnych zależy od poziomu przyznanych im ratingów uznawanych za warunek wstępny poszukiwana zewnętrznych źródeł finansowania na rynkach papierów wartościowych. Ocena kredytowania emitenta decyduje 
o oprocentowaniu, jakie musi on oferować celem uzyskania zewnętrznego finansowania. W niektórych państwach produkty inwestycyjne mogą być sprzedawane wyłącznie w przypadku wykazania przez emitenta odpowiedniego poziomu wiarygodności kredytowej potwierdzonej przez agencję ratingową o uznanej reputacji (Brylak, 2011, s. 320-321).

Oprócz prywatnego arbitrażu i agencji ratingowych wśród podmiotów „private governance” działających na rynku można wyróżnić prywatne organizacje, takie jak Międzynarodowa Organizacja Standaryzacji, stanowiąca w rzeczywistości sieć składającą się z ok. 180 komitetów, 550 podkomitetów i 2 tys. grup roboczych (Mattli, Büethe, 1993). Innymi, jeszcze bardziej złożonymi przykładami są hybrydowe, publiczno-prywatne instytucje regulacyjne, takie jak: Internetowa Korporacja ds. Nadawania Nazw i Numerów (ang. The Internet Corporation for Assigned Names and Numbers) zajmująca się przyznawaniem nazw domen internetowych, ustalaniem ich struktury, a także ogólnym nadzorem nad działaniem serwerów $\mathrm{DNS}^{7}$ na całym świecie oraz Komisja Kodeksu Żywnościowego (Codex Alimentarius Commission) $^{8}$. Komisja ta zajmuje się standardami

${ }^{7}$ System nazw domenowych (DNS) jest rozwiązaniem zapewniającym zamianę adresów domenowych na adresy IP. Dzięki wykorzystaniu DNS nazwa mnemoniczna, np. uke.gov.pl, może zostać zamieniona na odpowiadający jej adres IP (w tym wypadku 193.227.131.12). Por. http://www.dns.pl/ENUM/dokumenty/2007_09_10_ENUM.pdf, 3.22.2013.

${ }^{8}$ Codex Alimentarius, czyli Kodeks Żywnościowy (z łac. - kod żywienia) oznacza szereg zarówno ogólnych, jak i szczegółowych standardów zapewniania bezpieczeństwa żywności. Jego celem jest ochrona zdrowia konsumenta oraz gwarancja stosowania uczciwej praktyki w branży żywnościowej. Żywność wprowadzana na rynek lokalny czy też wysyłana na eksport musi być bezpieczna i dobrej jakości. Codex Alimentarius został utworzony w 1960 roku wspólnie przez dwie agendy Organizacji Narodów Zjednoczonych: Organizację do Spraw Wyżywienia i Rolnictwa (Food and Agriculture Organization - FAO) i Światową Organizację Zdrowia (World Health Organisation - WHO). Jego celem było wprowadzenie oraz propagowanie definicji oraz wymagań dla żywności ułatwiających harmonizację międzynarodowego obrotu żywnością. W pracach nad Kodeksem Żywnościowym bierze udział 166 państw, które skupiają większość ludności świata. Ustalenia międzynarodowe są następnie wprowadzane w życie również na szczeblu krajowym i regionalnym. Codex Alimentarius jest opracowywany przez Komisję Kodeksu Żywnościowego (Codex Alimentarius Commission), która jest międzyrządowym ciałem z równym głosem wszystkich państw członkowskich. Za projekty standardów są odpowiedzialne różne specjalistyczne komitety, które opracowują wstępne wersje standardów. Szerzej na ten temat na stronie internetowej Instytutu Żywności i Żywienia im. prof. dra med. Aleksandra Szczygła http://www.izz.waw.pl/pl/eufic?id=107, 3.11.2013. 
bezpieczeństwa żywności. Współpracuje przy tym zarówno ze środowiskami biznesowymi, jak również organizacjami międzynarodowymi. Do tych ostatnich zalicza się WTO, która odpowiada za przestrzeganie Porozumienia $\mathrm{w}$ sprawie stosowania środków sanitarnych i fitosanitarnych (Official, 1994), przyjętego jako jeden z wymiernych rezultatów wyniku rundy urugwajskiej GATT (Rewizorski, 2011, s. 28-39; Prévost, van den Bossche, 2005, s. 231-370; Scott, 2007).

Analizując czynniki wpływające na rozwijanie mechanizmów zarządzania globalnego warto też wskazać na pojawianie się transrządowych sieci regulacyjnych (trans-governamental regulatory networks). Ann Mary Slaugther - doradca prezydenta Baracka Obamy w zakresie polityki zagranicznej i bliski współpracownik Hilary Clinton - uważa, że zarządzanie globalne należy rozumieć raczej jako strukturę sieciową niż wynik działań poszczególnych państw. W często cytowanym eseju zauważa ona, że ,postrzeganie świata z optyki raczej podzielonych niż jednolitych państw pozwala liderom, politykom, analitykom czy po prostu zainteresowanym obywatelom dostrzegać cechy globalnego systemu politycznego, które wcześniej były ukryte. Sieci rządowe nagle pojawiają się wszędzie, od Grupy Specjalnej ds. Przeciwdziałania Praniu Pieniędzy [The Financial Action Task Force - FATF - M.R.], tj. sieci ministrów finansów i innych regulatorów finansowych przeciwdziałających praniu brudnych pieniędzy i finansowaniu terroryzmu, przez Komisję Wolnego Handlu [The Free Trade Commission - M.R.] - sieć ministrów handlu władnych interpretować Północnoamerykański Układ o Strefie Wolnego Handlu (NAFTA), po sieć ministrów spraw wewnętrznych odpowiedzialnych za zapewnienie bezpieczeństwa na granicach w następstwie wydarzeń z 11 września 2011 roku. Jednocześnie można dostrzec podziały zachodzące w organizacjach międzynarodowych, zwłaszcza «sieci wertykalne» tworzone między regulatorami narodowymi i ich ponadnarodowymi odpowiednikami" (Slaugther, 2004, s. 5-6).

Przychylając się do stanowiska A. M. Slaughter, warto zauważyć, że globalne sieci powiązań odgrywają zasadniczą rolę w tworzeniu, rozwijaniu, dyfuzji i implementacji rozmaitych norm, zasad i regulacji obejmujących coraz to nowe dziedziny, począwszy od nadzoru bankowego, a skończywszy na polityce ochrony zdrowia. Sieci te przyspieszają wymianę informacji. Generują także zasady służące wypełnieniu ogólnych uzgodnień osiąganych na szczytach głów państw i szefów rządów. Należy przy tym zauważyć, że większość z nich ma charakter techniczny i przyjmuje postać miękkiego prawa, a także rozmaitych deklaracji i memorandów 
(Reinecke, 1998). Slaughter utrzymuje, że transrządowe sieci regulacyjne bardziej efektywnie „wnikają” w suwerenność i czerpią z doświadczeń publicznych i prywatnych aktorów. Cechuje je nieformalność, elastyczność, nieprzenikalność dla opinii publicznej i łatwość adoptowania się do nowych problemów i sytuacji. Dzięki temu mogą one unikać stosowania tradycyjnych procedur negocjacyjnych charakterystycznych w relacjach między państwami. Ponadto sieci te zyskują na efektywności dzięki bliskim związkom między rozwijanymi normami i zasadami postępowania a ich implementacją i egzekwowaniem. Jak słusznie zauważa A. M. Slaughter, ,aktorzy, którzy tworzą zasady lub formułują reguły rządzące sieciami zarządzania są tymi samymi, którzy mają władzę, by zapewnić ich egzekwowanie" (Slaughter, 2000, s. 206). W tymże modelu centralne założenie sprowadza się do twierdzenia, że współczesny świat przestał opierać się na sztywnych zależnościach. Przyjął natomiast kształt pajęczej sieci, gdzie korzyści biorą się raczej z wzajemnych, dość luźnych powiązań niż inkluzji (Slaughter, 1997, s. 183-197; Slaughter, 2004; Slaughter, 2005, s. 281-295; Slaughter, 2009, s. 94-113). Zaczął tym samym przypominać globalny rynek, na którym - jak już wspomniano - sformalizowane reguły narzucane przez państwo ulegają osłabieniu, a zarządzanie nabiera charakteru gospodarczego i finansowego i jest w dużej mierze określanie przez podmioty niepaństwowe, dysponujące tzw. władztwem prywatnym, a także organizacje ponadnarodowe, które jak pokazuje przykład uczestnictwa Komisji Europejskiej w G-8, z biegiem czasu potrafią wyemancypować się spod kurateli państw.

\section{Zakończenie}

W dobie rozprzestrzeniającej się globalizacji coraz więcej uwagi poświęca się rynkom i ich „władzy”, będącej w istocie „władzą globalizacji”, a także instytucjom i podmiotom rynkowym. Jej ekonomiczny wymiar zdominowany jest przez myślenie neoliberalne skoncentrowane na ukazywaniu ścisłego związku między swego rodzaju władztwem podmiotów rynkowych, a rynkiem jako przestrzenią ich działania, gdzie mogą aktualizować swój potencjał. Mnożenie się grup biznesowych, przedsiębiorstw międzynarodowych, transnarodowych grup nacisku, słowem rozprzestrzenianie się globalnych sieci powiązań jest skorelowane z pozyskiwaniem przed podmioty niepaństwowe nowych kompetencji, przez co kształtowanie zrębów międzynarodowej polityki ekonomicznej w coraz mniejszym 
stopniu należy do państw. Te ostatnie uzależnione są od zmian zachodzących na poszczególnych rynkach. Można znaleźć wiele przykładów uzasadniających to twierdzenie. Jednym z nich jest dramatyczna sytuacja koncernu telekomunikacyjnego Nokia, stanowiącego od wielu lat „,motor" fińskiej gospodarki. Przyczyn tego stanu rzeczy można dopatrywać się w offshoringu, w ramach którego część fabryk produkujących telefony firmy Nokia przeniesiono z Salo (Finlandia) i Kluzu (Rumunia) do Azji (Chiny, Korea Południowa, Indie oraz Wietnam), a także spadku udziału Nokii na globalnym rynku telefonów komórkowych i smartfonów ${ }^{9}$ na rzecz Apple'a i Samsunga. Do 2014 roku koncern ten zapowiedział likwidację w różnych państwach 10 tys. miejsc pracy, pozostawiając jedynie zakłady w Finlandii, a także placówkę badawczo-rozwojową w niemieckim Ulm, zatrudniającą 730 osób. Planowane redukcje zatrudnienia oznaczają, że od września 2010 r. pracę w Nokii może stracić ponad 40 tys. osób ${ }^{10}$. Sytuacji tej od lat bezskutecznie próbuje zaradzić nie tylko fiński rząd, ale także UE, która w 2013 r. na pomoc dla zwolnionych pracowników koncernu przeznaczyła 9,81 mln euro pochodzących z zasobów Funduszu Dostosowania do Globalizacji.

Powyższy przykład wskazuje na negatywne aspekty ,władzy globalizacji”. Globalny rynek, transnarodowa przestrzeń wymiany, jest kształtowana w dużej mierze przez podmioty prywatne. Claire Cutler, Virginia Haufler i Tony Porter przekonują nawet o istnieniu ,transnarodowych reżimów prywatnych”, które definiują jako „,zintegrowane zbiory formalnych i nieformalnych instytucji, będące źródłami zarządzania obszarem zagadnień ekonomicznych" (Cutler, Haufler, Porter, 1999, s. 13). Coraz więcej dowodów świadczy o tym, że ich działanie może w określonych warunkach wywoływać bardzo negatywne konsekwencje i prowadzić do

9 Udział Nokii w rynku podstawowych modeli telefonów komórkowych spadł z 33\% (2010 r.) do 24\% (2011) i spadek ten trwał nadal w 2012 r. W drugim kwartale 2012 r. Nokia utrzymywała udział w rynku w wysokości 6,6\% (spadek z 38\% na początku 2010 r.), podczas gdy Apple miało 16,9\%, a Samsung 32,6\%. Cf. Wniosek w sprawie Decyzji Parlamentu Europejskiego i Rady w sprawie uruchomienia Europejskiego Funduszu Dostosowania do Globalizacji, zgodnie z pkt 28 Porozumienia międzyinstytucjonalnego z dnia 17 maja 2006 r. pomiędzy Parlamentem Europejskim, Rada $i$ Komisja w sprawie dyscypliny budżetowej i należytego zarzqdzania finansami (wniosek EGF/2013/001 FI/Nokia Salo z Finlandii), COM(2013) 707 final, Bruksela, dnia 16.10.2013, s. 3-4.

10 Informacje dostępne na stornie internetowej: http://it.inzynieria.com/cat/1/art/ 32499/kolejne-zwolnienia-grupowe-w-nokii, 20.01.2013. 
zwiększenia ryzyka wystappienia turbulencji finansowych oraz gospodarczych. Wystarczy tu przywołać niedawny przykład trzech największych amerykańskich agencji ratingowych, których funkcjonowanie ma wpływ na zachowania inwestorów i kondycje gospodarek największych państw na świecie, nie wyłączając Stanów Zjednoczonych. Jesienią 2008 r., na sześć dni przed upadkiem banku Lehman Brothers, agencja Standard \& Poor's podtrzymała rating inwestycyjny dla niego na poziomie „A”. Moody's czekał jeszcze dłużej, obniżając rating na jeden dzień roboczy przed upadkiem tego banku. Nie dziwi, że wobec różnych podmiotów „private governance” stawia się wiele pytań, wśród których najważniejsze dotyczą tego, czy władztwo przysługujące podmiotom prywatnym, działającym na rynkach, jest im przez państwa dane, umożliwione, czy raczej „wymyka się” państwom z rąk oraz czy współczesne państwo może zapewnić sprawne działanie mechanizmów pozwalających na pogodzenie rozwoju podmiotów prywatnych z celami polityki wewnętrznej.

Odpowiedzi na te pytania utrudnia fakt, że na globalnym rynku obok państw i podmiotów prywatnych funkcjonują agenci ponadnarodowi, a także organizacje międzyrządowe, takie jak Międzynarodowy Fundusz Walutowy (MFW), cechujące się znacznym stopniem autonomii wobec państw. Przykład MFW wskazuje, że organizacje takie wywierają poważną presję na państwa, występując w roli kredytodawcy ostatniej szansy i niejednokrotnie decydując o relokacji przedsiębiorstw, zakresie ich restrukturyzacji, rozmiarach zatrudnienia. Jeśli dodać do tego zwiększającą się mobilność kapitału i rosnącą rywalizację miedzy państwami, jako odbiorcami globalnego kapitału, często gotowymi iść na znaczne ustępstwa, by go przyciagnąć, zrozumiałe staje się postrzeganie rynków jako „organizmów” zdolnych do „nagradzania lub karania w zależności od oceny tego, jak rządy radzą sobie z podażą pieniądza, deficytami budżetowymi, zadłużeniem zagranicznym, deregulacją [...] karteli bankowych, zwiększeniem efektywności banków i ich lokalnych rynków kredytowych" (Strange, 1997, s. 9). To jedna strona medalu. Jest i druga. Rynek może być dla państwa bardzo pomocny, a to z tego względu, że rządy często obarczają go winą za niepowodzenia w prowadzonej przez siebie polityce ekonomicznej. W ten sposób upraszczają rzeczywistość polityczną, budując podział na to, co dobre, wewnętrzne, krajowe, przewidywalne, kolektywne, słowem „nasze” i to, co złe, bo zewnętrzne, kryzysowe, obce, niebezpieczne, niestabilne. Takie rozumowanie i rozmywanie odpowiedzialności przez rządy wobec społeczeństw za podejmowane działania nie może trwać jednak w nieskończoność. Niewydolność państwa i samowola 
podmiotów rynkowych może się bowiem stać przyczyną utraty władzy przez rządy niezdolne do tego, by trzymać w ryzach kapitał. Rynki dla swojego trwania i rozwoju potrzebują politycznej stabilności i podstaw instytucjonalnych, które zapewnia państwo. Odpowiednio wykorzystywane stanowią narządzie polityki państwowej, nie mogą być jednak jej substytutem. I tutaj pojawia się zasadnicza wątpliwość. Z jednej strony wydaje się, że współczesne państwo, funkcjonujące w dobie globalizacji przesiąkniętej ideami neoliberalnymi, powinno wobec rynku odgrywać rolę zarządcy kryzysowego, gotowego wespół z organizacjami międzynarodowymi wkraczać zawsze wszędzie tam, gdzie stabilność rynku staje pod znakiem zapytania i pojawia się groźba wybuchu kryzysu społeczno-ekonomicznego. $Z$ drugiej strony przebieg kryzysu finansowego i gospodarczego, którego symbolem stał się upadek banku Lehman Brothers w 2008 roku wskazał, że nawet skoordynowane działania państw skupionych w G-8 i G-20 stają się niewystarczające, a przywrócenie stabilności rynków wydaje się, przynajmniej w krótkookresowej perspektywie, przykładem myślenia życzeniowego (ang. wishful thinking). Pojawia się zatem pytanie, co może się wydarzyć, jeśli podobne kryzysy będą częstsze i bardziej intensywne. Wydaje się, że jednym z prawdopodobnych scenariuszy jest przejęcie funkcji regulacyjnej i stabilizacyjnej w przestrzeni rynkowej przez dawnych agentów państw, obecnie wciąż dzierżycieli legitymizowanej władzy publicznej. Być może ekspansja podmiotów prywatnych, organizacji trans- i ponadnarodowych, a także stopniowe powiększanie ich władztwa w myśl zasady ,zbyt duży by upaść” jest pierwszym tego zwiastunem.

\section{Bibiliografia}

Ammer J. M., Packer F. (2000), How Consistent Are Credit Ratings? A Geographic and Sectorial Analysis of Default Risk, FRB International Finance Discussion Paper, No. 668.

Boot A. W. A., Tood T. M., Schmeits A. (2006), Credit Ratings as Coordination Mechanisms, „Review of Financial Studies”, Vol. 19(1).

B20 (2013a), B20-G20 Partnership for Growth and Jobs: Recommendations from Business 20, http://www.b20russia.com/B20_WhiteBook_web.pdf, 27.09.2013.

B20 (2013b), From Toronto to Saint Petersburg: Assessing G20-B20 Engagement Effectiveness: Draft Report, www.hse.ru/data/2013/06/24/1287462471/ G20-B20_engagement_effectiveness_report_full.pdf, 27.09.2013. 
Biersteker T. J., Hall R. B. (red.) (2002), The Emergence of Private Authority in Global Governance, Cambridge University Press, Cambridge.

Brown G. W., Globalization is What We Make of It: Contemporary Globalization Theory and the Future Construction of Global Interconnection, „Political Studies Review" 2008, Vol. 6, nr 1.

Brylak J. (2011), Agencje ratingowe na rynku inwestycji. Prawne aspekty instytucji, Polskie Towarzystwo Naukowe, „Zeszyty Naukowe”, nr 11.

Commission on Global Governance (1995), Our Global Neighbourhood, Oxford University Press, New York.

Cutler C., Haufler V., Porter T. (red.) (1999), Private Authority and International Affairs, SUNY Press, New York.

Gates B. (2011), Innovation with Impact: Financing 21st Century Development, Cannes, http://www.thegatesnotes.com/ /media/Images/GatesNotes/G20/G20-Documents/g20-report-english.pdf, 28.09.2012.

Hajnal P. (2007), The G-8 system and the G-20: evolution, role and documentation, Ashgate, Aldershot.

Harvey D. (2005), A Brief History of Neoliberalism, Oxford University Press, Oxford.

Kołodko G. (2013), Dokad zmierza świat. Ekonomia polityczna przyszłości, Warszawa.

Kołodko G. (2010a), Neoliberalizm i światowy kryzys gospodarczy, „Ekonomista”, nr 1 .

Kołodko G. (2010b), Neoliberalizm i systemowy kryzys globalnej gospodarki, w: Globalizacja, kryzys i co dalej?, red. G. Kołodko, Warszawa 2010.

Kołodko G. (2008), Wędrujacy świat, Warszawa.

Łoś-Nowak T. (2011), Polityka zagraniczna w przestrzeni teoretycznej, w: Polityka zagraniczna. Aktorzy - potencjały - strategie, red. T. Łoś-Nowak, Poltext, Warszawa.

Mandel E., Late Capitalism, Verso Books, London 1975.

Mattli W. (2001), Private Justice in a Global Economy: From Litigation to Arbitration, „International Organization”, Vol. 55.

Mattli W., Büethe T. (1993), Setting International Standards: Technological Rationality or the Primacy of Power, ,World Politics”, Vol. 56.

Murphy C. N. (1994), International Organization and Industrial Change. Global Governance since 1850, Polity Press, Cambridge.

Naím M. (2009), Think Again: Globalization, „Foreign Policy”.

Official Journal of the European Communities L 336, 23/12/1994.

Overbeek H. (2005), Global governance, class, hegemony. A historical materialist perspective, w: Contending Perspectives on Global Governance. Coherence, contestation and world order, red. A. D. Ba, M. J. Hoffman, Routledge, London-New York. 
Pietrzak E. (2013), Niepostuszeństwo i profanacje-globalne społeczeństwo obywatelskie, „Przegląd Politologiczny”, nr 1.

Prévost D., Van den Bossche P. (2005), The Agreement on the Application of Sanitary and Phytosanitary Measures, w: The World Trade Organization: Legal, Economic and Political Analysis: Volume I, red. P. F. J. Macrory, A. E. Appleton, M. G. Plummer, Springer, New York 2005.

Reinecke W. (1998), Global Public Policy: Governing without Government?, Brookings, Washington, DC.

Rewizorski M. (2011), The WTO Legal System, Volume 2. The Uruguay Round Agreements (Agreement Establishing the World Trade Organization - Annex 1A), Offset, Kołobrzeg.

Scott J. (2007), The WTO Agreement on Sanitary and Phytosanitary Measures: A Commentary, Oxford University Press, Oxford.

Slaughter A. M. (1997), A New World Order, „Foreign Affairs”, Vol. 76, nr 5.

Slaugther A. M. (2004), A New World Order, Princeton University Press, Princeton.

Slaughter A. M. (2000), Governing the Global Economy through Government Networks, w: The Role of Law in International Politics, red. M. Byers, Oxford University Press, Oxford.

Slaughter A. M. (2005), Government Networks, World Order, and the L20, w: Reforming from the Top: A Leaders'20 Summit, red. J. English, R. Thakur, A. F. Cooper, United Nations University Press, Tokyo 2005.

Slaughter A. M. (2009), America's Edge: Power in the Networked Century, „Foreign Affairs", Vol. 88, nr 1.

Słojewska A. (2011), Agencje: wróg publiczny nr 1, „Rzeczpospolita”, 15.07.2011.

Standard \& Poor's: http://www.standardandpoors.com/ratings/sovereigns/ratingslist/ en/eu/?subSectorCode=39\&start=50\&range $=50,3.11 .2013$.

Strange S. (1997), Territory, State, Authority, Economy: A New Realist Ontology of Global Political Economy, w: The New Realisms: Perspectives on Multilateralism and New World Order, red. Robert W. Cox, United Nations Press, Tokyo.

Streeck W., Schmitter P. C. (1985), Community, Market, State-and Associations?, „European Sociological Review”, Vol. 1.

The Stanley Foundation (2009), Courier. Waiting to Join the Club, No. 63.

WTO (2007), Understanding the WTO, Geneva.

Żyżyński J. (2009), Neoliberalizm jako strukturalna przyczyna kryzysu a poszukiwanie dróg naprawy, „Ekonomista”, nr 2.

Zürn M. (1995), The Change of Globalization and Individualization: a View from Europe, w: Whose World Order? Uneven Globalization and the End of Cold War, red. H. H. Holm, G. Sørensen, Boulder, Westview. 
The role of the market in forming global governance

\begin{abstract}
Summary
This text reflects on the role of the global market, defined as the space where various relations between states and private entities take place. The following examples are provided in the case of the latter: private arbitration, rating agencies, International Standard Organisation, The Internet Corporation for Assigned Names and Numbers, and Codex Alimentarius Commission. The market is depicted in the context of a number of economic and financial phenomena constituting the contemporary face of globalization. The article also presents the diverging standpoints of researchers as concerns the role attributed to the market in global governance as the space of activities of non-state entities, especially considering the fact that - as a more and more vital holder of power exceeding that of state powers - private structures are acquiring broad autonomy within national and international law. Thereby, they become important regulators of jurisdiction and the international economy. From this perspective, globalization leads to the extension of the scope of rules regulating more and more fields of economic activity conducted beyond national borders. The further weakening of the role states have in relation to market powers and entities involved in a broad range of actions in economy, trade, and international finances is therefore plausible.
\end{abstract}

